\title{
Efficiency of apparel retail at the firm level-- an evaluation using data envelopment analysis (DEA)
}

\begin{abstract}
In this study, the author employed data envelopment analysis (DEA) to assess the productivity efficiency of the top apparel retailers in the world. Four input variables and two output variables are chosen to do the empirical study; the data are retrieved from Capital IQ database in the University of Manchester. The result shows that 19 apparel retailers are efficient among the 42 samples that this study identified. Meanwhile, the benchmark targets are proposed for the remaining 23 less efficient companies, they can improve their productivity efficiency either by decrease the spending on specific input variables or by increase their outcome after review the value chain. This study contributes to the understanding of apparel retail performance at corporate level. It is expected the findings can have profound implications for companies being analyzed to understand the efficiency of utilizing resources into measurable outcomes and how to improve their efficiency.
\end{abstract}

Keywords: efficiency, Data Envelopment Analysis (DEA), apparel retailers, benchmarking, firm level
Volume 4 Issue 2 - 2018

\author{
Shuangyan Li, ${ }^{1,2}$ Stephie Tsai ${ }^{3}$ \\ 'Textile School, Zhongyuan University of Technology, China \\ ${ }^{2}$ Department of Education Henan Province, Key Laboratory of \\ Functional Textiles, China \\ ${ }^{3}$ School of Materials, The University of Manchester, UK
}

Correspondence: Shuangyan Li, Textile School, Department of Education Henan Province, Key Laboratory of Functional Textiles, University of Technology, No.4I zhongyuan Road, Zhengzhou, Henan Province, China, Tel 0086-13663808485, Fax 0086-037I62506970,Email shuangyanli@I26.com

Received: February 0I, 2018 | Published: March 12, 2018

\section{Research background}

The apparel industries are composed of a series of interrelated industries from the manufacturing of fibre and fabric to apparel and ultimately the distributor and retailer that connect the final consumers. This is often referred to as the textile/apparel pipeline. ${ }^{1}$ Firms in apparel industries often involved in two stages in the textile/ apparel supply chain, namely apparel production and retailing. The performance depends heavily on the efficiency of costing and retailing. ${ }^{2}$ Production cost has been an important factor in the pricing of apparels. However, this has changed as the operating cost increased significantly proportionally over the years. ${ }^{3,4}$

\section{Trend of distribution in apparel industry}

Traditionally, apparel manufacturers distribute their products in three ways, some do their own retailing, some distribute to other retailers, and some sell to distributors. ${ }^{5}$ Manufacturers held a powerful position in distribution channels as they possess the source innovations up until the mid-1960s. ${ }^{1}$ Changes have taken place as retailers began to source from a large number of manufacturers and geographical locations. ${ }^{3}$ Apparel companies began to establish retail divisions and sell items by themselves. ${ }^{6}$ As such kind of stores dedicated to a single brand, apparel corporates can control over branding and merchandising and highlight its own merchandise, and without worrying about competing labels. ${ }^{3}$ The basic competition between the apparel companies has gone beyond production to the management of retailing activities. ${ }^{1,7}$

\section{Global apparel retailer}

Retailer plays more and more important role in our social life. WalMart revolutionized manufacturer-retailer relationships, eliminated considerable costs in the value chain. When we referred to the Sears, the customers can call in mind with a great deal of items rather than the brand names of the items sold.
As the apparel industry is simple technologically and is relatively labour-intensive, ${ }^{8}$ it is of low barriers to entry. ${ }^{9}$ There is a large numbers of similar apparel retailers existing, however, a large numbers of players are entering in this industry. ${ }^{1}$ The competition becoming increasingly fierce. ${ }^{7,10}$ Retailers, large retailers in particular, started to increase their control over the supply chain and gained stronger bargaining power against apparel manufacturers. ${ }^{11,12}$

According to the Global Apparel Retail (2014), the apparel retail market is highly concentrated, several large corporations, such as Inditex, Gap and $H \& M$, accounted for a significant share of total industry revenues. The leading distribution channel of the global apparel retail industry accounts for $61.8 \%$ share of the total value. ${ }^{9}$

\section{Purpose of this research}

In recent years, the competition between the global apparel retailers become more and more intensifying, Larger companies such as TJX Companies, Inditex, $\mathrm{H} \& \mathrm{M}$, are more profitable than the smaller ones as they can offer wide selections of clothing. ${ }^{3,9}$ Global apparel retailers are trying their best to improve their revenues in the case of not changing their current input factors. That is to say, how to improve the managing efficiency is of vital to the apparel retailers.

As many of apparel retailers now have multi-channel retailing, the sales generated from brick and mortar retailing is decreasing. Measuring store-level efficiency would not be able to capture the fastgrowing sales that are generated from online and mobile.

The purpose of this study is to investigate the efficiency of these large global apparel retailers at the corporate level, assess productivity of top apparel retailers in the world. It would be useful to know whether these corporates are run under optimal condition.

\section{Literature review and theoretical framework}

Productivity is originally used in the manufacturing process, ${ }^{13}$ it is defined as a ratio of output to input, a higher ratio of measured 
output to measured input factors can be directly interpreted as higher productivity. ${ }^{13,14}$

According to the British Institute of Management, ${ }^{15}$ Productivity can be interpreted as productiveness or efficiency. It is involved with the utilization of resources, namely, how to produce a given output by using the minimum input rather than the simply rate of output to input. ${ }^{15}$ In this study, the terms "productivity" and "efficiency" will be used as synonyms as they are both used in quite a number of previous studies. ${ }^{16,17}$

For the global apparel retailers, productivity assessment can be used to control and manage tactical, strategic and policy related decisions within a corporate, ${ }^{14,18}$ retail productivity was considered very important for the individual retail firms. ${ }^{19}$

\section{Measurement of retail productivity}

Different academicians targeted to the different level in measuring retail productivity, for example, a single retail store chain, ${ }^{2}$ retailers in a specific category, ${ }^{16,20,21}$ and the retail industry as a whole. ${ }^{18,22}$ Also, despite the long history of retail productivity research, "there is still no single widely accepted definition and measurement methodology for retail productivity". ${ }^{16}$

In the recent decades, there have been many new techniques for evaluating retail productivity. Table 1 lists the methodology that used in the literature in recent years. We can conclude from the Table 1 that DEA is the prevalent method in the measurement of retail productivity. ${ }^{23-27}$

Table I Analysis of retail productivity

\begin{tabular}{|c|c|c|}
\hline Authors & Method & Units \\
\hline Reynolds, Howard et al. & TFP & over 200 US, UK and French retail companies \\
\hline Barros & DEA & $\begin{array}{l}22 \text { hypermarkets and supermarkets in the Portuguese } \\
\text { market:1998-2003 }\end{array}$ \\
\hline Akanksha Gupta* and Sanjiv Mittal & DEA & 43 India grocery retailers \\
\hline Perrigot and Barros & DEA & II French generalist retailers \\
\hline Mostafa & DEA & 45 US specialty retailers and food consumer stores in 2007 \\
\hline Thomas et al. & DEA & $\begin{array}{l}552 \text { domestic retail outlets of a leading specialist retailer in the } \\
\text { USA }\end{array}$ \\
\hline Barros and Alves & $\begin{array}{l}\text { DEA-CCR and BCC } \\
\text { model }\end{array}$ & 47 outlets of a Portuguese hypermarket retailcompany: 1999-2000 \\
\hline Keh and Chu (2003) & DEA BCC model & I 3 US stores 1988-1997 \\
\hline $\begin{array}{l}\text { Wantao Yu and Ramakrishnan } \\
\text { Ramanathan }\end{array}$ & DEA /MPI & 4I retail companies in UK \\
\hline
\end{tabular}

\section{Input and output variables employed in the DEA methodology}

From the previous analysis, we know that DEA has been one of the key measurement methods to assess the retail productivity, see Table 1 . The challenge of productivity measurement lies primarily on the selection of output and input variables..$^{21,28}$ As the selected input variables need to represent the key elements that are required to produce the product and/or deliver the services, ${ }^{16,18,21}$ different authors used different variables to define the retail productivity. Gupta and Mittal chose sales and customer conversion ratio as output variables,$^{21}$ input variables are number of employees, cost of labour, number of hours worked by the workers, numbers of POS machines/ checkout counters, area of outlets (size of the store) and number of Stock Keeping Units (SKUs) to measure retail productivity of food \& grocery retail outlets. ${ }^{21} \mathrm{Keh}$ and Chu used labour and capital as input variables, accessibility, assortment, assurance of product delivery, availability of information and ambience as output variables to measure productivity of a chain of grocery stores..$^{22}$ Mostafa, ${ }^{17}$ Barros \& Alves, ${ }^{2}$ Reynolds et al. ${ }^{13}$ choose the different variables respectively to measure the relative efficiency that they studied.

\section{DEA methodology}

Data envelopment analysis (DEA) is introduced by Charnes et al. ${ }^{29}$ in 1978; it is a powerful model to differentiate the most efficient units within a set of comparable decision making units (DMUs) by identifying a frontier. Hereby, the units can be production units, such as firms, or service units such as banks, schools etc. Unlike measuring one input-output ratio at one time in ratio analysis, DEA methodology can measure the combining efficiency based on multi-input and multioutput parameters.

\section{The constant returns to scale (CRS) --CCR model}

The original objection of DEA was to form an efficient frontier that comprising best units, identify the best practices and provide a methodology to maximize the efficiency value of a test firm $\mathrm{k}$ from a reference set of s firms, by selecting the optimal weights associated with the input and output measures. The maximum efficiencies are constrained to 1 . There are two ways of input-orientated and outputorientated measures to identify weather a firm is of efficient or not. Input-oriented measure address the question: "By how much can input quantities be proportionally reduced without changing the output quantities produced?" Output-oriented efficiency answer the question 
that by how much can output quantities be proportionally expanded without altering the input quantities used.

Basic DEA model is proposed by Charnes, Cooper and Rhodes (CCR) in 1978, and which is assumed as constant returns to scale (CRS). Under the circumstance of the CRS assumption, all the DMUs are operating at optimal scale no matter the size of the firms.

\section{The variable returns to scale (VRS) --BCCmodel}

In the CCR model, it is assumed that an increased amount of input will proportionately increase the amount of output produced. Actually, the imperfect competition, constraints on finance etc. may cause a DMU to be not operating at the optimal frontier. Banker, Charnes and Cooper $(\mathrm{BCC}, 1984)$ later extended the CCR model to BCC model, which assumed that the amount of output produced is considered to increase more or less than the proportional increase in the inputs, that is to say, with a variable return to scale (VRS). The BCC model can be interpreted as the following formula:

$$
E_{j}=\sum_{r=1}^{s} u_{r} Y_{r j} / \sum_{i=1}^{m} v_{i} X_{i j}
$$

Subject to: $\sum_{r=1}^{s} u_{r} Y_{r j} / \sum_{i=1}^{m} v_{i} X_{i j} \leq 1, \mathrm{j}=1,2 \ldots, \mathrm{n}$

$u_{r}, v_{i} \geq 0 ; \mathrm{r}=1, \ldots, \mathrm{s} ; \mathrm{i}=1, \ldots, \mathrm{m}$

If $E_{j}=1$, It means that no other firm is more efficient than the firm $j$ for its selected weights. That is to say, firm $\mathrm{j}$ is on the optimal frontier and is not dominated by any other firm. If $E_{j}<1$, then the firm $\mathrm{j}$ does not lie on the optimal frontier and there is at least one other firm that is more efficient than the firm $\mathrm{j}$.

When not all DMUs are operating at the optimal scale, the use of CRS will result in measures of technical efficiency (TE) are confounded by scale efficiency (SE). To the contrary, the use of the VRS specification will permit the calculation of TE devoid of the affects of SE.

\section{The methodology of this research}

In this research, BCC model will be employed to access the following objectives:

a. Assess the retail performance of the top apparel companies by using DEA methodology;

b. For those inefficient apparel companies, determine the ways to improve their efficiency;

c. To test the effectiveness of DEA measurement.

\section{Research process}

\section{Database and criteria}

To determine which company should be included in the analysis is very crucial as it may not be meaningful if including some companies which primary business is not apparel. The samples selected are taken from the database of S\&P Capital IQ in the University of Manchester, UK. S\&P Capital IQ provides industry leading fundamental data that is fully transparent, standardized, and integrated. With over $99 \%$ of the global market capitalization covered, this database provides comprehensive global coverage of more than 79,000 public companies and more than 700,000 private companies.

In our study, the searching criteria are: i. SIC Code: 5600 Apparel and accessory stores (Primary). Standard Industrial Classification (SIC) codes are used by the Department of Trade and Industry within the UK to define the scope of an industry. The primary business of the selected companies is apparel and accessory.

ii. Total Revenue (\$USD million, Historical rate) is greater than or equal to 500. This variable is the data of 2015 financial year.

After searching, 189 companies are selected.

\section{Principle of company cancellation}

The next step is to screen all the selected 189 companies as some candidates may not meet the requirement. The screening principles are as following:

a. If a group corporate has several sub-companies in the table, then remain the primary one, and cancel all the sub-companies.

b. Some companies miss some financial data in the database; their annual report doesn't refer to the variables either.

c. Some companies whose primary industry is not apparel, and apparel is only one branch of the whole group.

At last, 42 companies are reserved.

\section{Choosing the input and output variables}

According to the previous study, the input and output variables should reflect the main purpose of the study. This study is concerned about the retail performance of the top apparel retail companies, we choose the input variables as cost of goods sold (X1), total operating expenses (X2), total intangibles (X3), number of employees (X4), total stores (X5) and inventory (X6). These six variables reflect all aspects of input. Output variables are total revenue (Y1) and return on assets (ROA) (Y2), they can give an idea of management efficient of an company.

\section{Research result}

Generally, apparel retailers can't amplify their sales in a short period, we use the input-orientated DEA methodology in this study, which address the question that by how much input quantities can be proportionally reduced without changing the output quantities produced. After processing, the results are presented in this section.

\section{Efficiency scores and bench-marking companies}

DEA scores are given from 0 to 1 . Score 1 means that the firm under consideration is efficiency; the output obtained from a given amount of input is maximal. The efficiency companies are located on the efficiency frontier. Score 0 implies that the company is inefficiency, which is located within the efficiency frontier.

Table 2 lists the efficiency score of the 42 apparel companies in 2015. As explained in section 3, these efficiency scores were computed according to the inputs and outputs of all 42 companies, so these efficiencies are relative efficiency. Table 2 shows that 19 companies had a VRS efficiency score of 1.00 , and they are lie on the efficient frontier. 23 out of the 42 companies are inefficient (efficiency score is less than 1) and they are lie inside the frontier. Of the 23 inefficient companies, 22 companies had VRS efficiency between 0.80 and 1.00 , the most inefficient company is Pou Sheng International (Holdings) Ltd, whose efficiency score is 0.795 . 
Table 2 Efficiency scores of apparel companies in 2015

\begin{tabular}{|c|c|c|c|c|c|c|}
\hline S.No & Company & CRS & VRS & Scale & RTS & Reference set \\
\hline I & The TJX Companies, Inc. (NYSE:TJX) & 0.936 & 1 & 0.936 & DRS & 1 \\
\hline 2 & Industria de Diseno Textil SA (CATS:ITX) & 1 & 1 & I & CRS & 2 \\
\hline 3 & H \& M Hennes \& Mauritz AB (publ) (OM:HM B) & 1 & 1 & I & CRS & 3 \\
\hline 4 & The Gap, Inc. (NYSE:GPS) & 0.899 & 0.926 & 0.971 & DRS & 1112310 \\
\hline 5 & Fast Retailing Co. Ltd. (TSE:9983) & 1 & 1 & I & CRS & 5 \\
\hline 6 & Nordstrom Inc. (NYSE:JWN) & I & 1 & I & CRS & 6 \\
\hline 7 & L Brands, Inc. (NYSE:LB) & 0.94 & 0.951 & 0.988 & DRS & 3152310 \\
\hline 8 & Ross Stores Inc. (Nasdaq GS:ROST) & I & 1 & I & CRS & 8 \\
\hline 9 & Foot Locker, Inc. (NYSE:FL) & 0.914 & 0.915 & 0.998 & IRS & 10536340 \\
\hline 10 & Next Plc (LSE:NXT) & 1 & 1 & 1 & CRS & 10 \\
\hline II & Shimamura Co. Ltd. (TSE:8227) & I & 1 & 1 & CRS & 11 \\
\hline 12 & Ascena Retail Group Inc. (NasdaqGS:ASNA) & 0.84 & 0.863 & 0.973 & DRS & 24031 \\
\hline 13 & Burlington Stores, Inc. (NYSE:BURL) & 0.866 & 0.894 & 0.968 & IRS & 610336 \\
\hline 14 & Abercrombie \& Fitch Co. (NYSE:ANF) & 1 & 1 & 1 & CRS & 14 \\
\hline 15 & American Eagle Outfitters, Inc. (NYSE:AEO) & 0.89 & 0.904 & 0.984 & IRS & 1110240 \\
\hline 16 & Esprit Holdings Ltd. (SEHK:330) & 0.865 & 0.918 & 0.943 & IRS & 401036541 \\
\hline 17 & Genesco Inc. (NYSE:GCO) & 0.836 & 0.841 & 0.995 & DRS & 31031 \\
\hline 18 & The Men's Wearhouse, Inc. (NYSE:MW) & 0.875 & 0.877 & 0.998 & IRS & 1031403 \\
\hline 19 & Chico's FAS Inc. (NYSE:CHS) & 0.966 & 0.983 & 0.982 & DRS & 40112 \\
\hline 20 & Edcon Holdings Limited & 0.812 & 0.813 & 0.999 & IRS & 104031 \\
\hline 21 & Brown Shoe Co. Inc. (NYSE:BWS) & 0.807 & 0.815 & 0.991 & IRS & 105314036 \\
\hline 22 & J. Crew Group, Inc. & 0.889 & 0.937 & 0.948 & IRS & 1035636 \\
\hline 23 & DSW Inc. (NYSE:DSW) & 0.919 & 0.945 & 0.973 & IRS & 863610 \\
\hline 24 & Aoyama Trading Company, Ltd. (TSE:82 I9) & 1 & 1 & 1 & CRS & 24 \\
\hline 25 & Express Inc. (NYSE:EXPR) & 0.921 & 0.951 & 0.968 & IRS & 1064140 \\
\hline 26 & Aéropostale, Inc. (NYSE:ARO) & 0.792 & 0.821 & 0.965 & IRS & II 40 \\
\hline 27 & Pou Sheng International (Holdings) Ltd. (SEHK:38I3) & 0.795 & 0.798 & 0.995 & IRS & 4010 \\
\hline 28 & AOKI Holdings Inc. (TSE:82 I4) & I & 1 & 1 & CRS & 28 \\
\hline 29 & Finish Line Inc. (NasdaqGS:FINL) & 0.924 & 0.935 & 0.988 & IRS & 40103536 \\
\hline 30 & Etam Developpement SA (ENXTPA:TAM) & 0.82 & 0.82 & 1 & CRS & 3139 \\
\hline 31 & Adastria Holdings Co., Ltd. (TSE:2685) & I & 1 & 1 & CRS & 31 \\
\hline 32 & Stage Stores Inc. (NYSE:SSI) & 0.805 & 0.879 & 0.915 & IRS & 8364135 \\
\hline 33 & Claire's Stores Inc. & 0.867 & 0.87 & 0.997 & IRS & 401031 \\
\hline 34 & Mr Price Group Limited (JSE:MPC) & I & 1 & 1 & CRS & 34 \\
\hline 35 & The Foschini Group Limited (JSE:TFG) & I & 1 & I & CRS & 35 \\
\hline 36 & United Arrows Ltd. (TSE:7606) & 1 & 1 & 1 & CRS & 36 \\
\hline 37 & Mothercare plc (LSE:MTC) & 0.761 & 0.844 & 0.902 & IRS & 2840313641 \\
\hline 38 & Maclntosh Retail Group NV (ENXTAM:MACIN) & 0.783 & 0.82 & 0.954 & IRS & 31403942 \\
\hline 39 & Charles Voegele Holding AG (SWX:VCH) & I & 1 & 1 & CRS & 39 \\
\hline 40 & Truworths International Ltd. (JSE:TRU) & 1 & 1 & 1 & CRS & 40 \\
\hline 41 & New York \& Company Inc. (NYSE:NWY) & 0.864 & 1 & 0.864 & IRS & 41 \\
\hline 42 & Reitmans Canada Ltd. (TSX:RET.A) & 0.958 & 1 & 0.958 & IRS & 42 \\
\hline
\end{tabular}

RTS: return to scale, CRS-constant, IRS-increasing, DRS-decreasing 
Accordingly, the peer count number can be considered as a measure of the extent to which the performance of an efficient retailer can be a useful benchmark for the non-efficient ones. The efficiency companies and its benchmark times were showed in Figure 1.

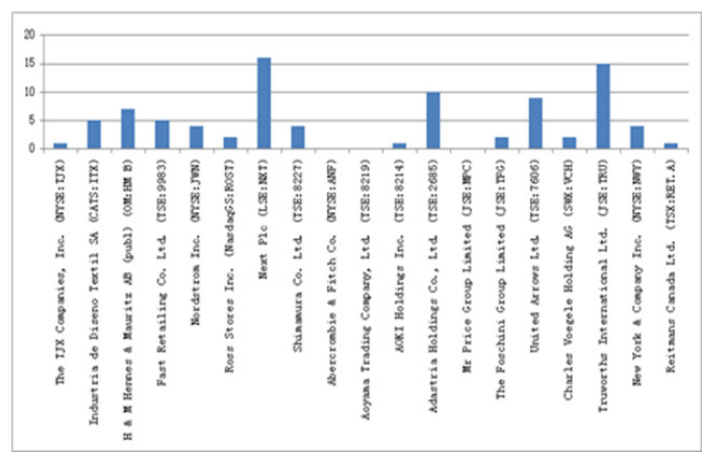

Figure I Efficiency companies and its benchmark times.

Of these efficient companies, the most frequently benchmarked company is Next Plc, which is the most distinguished company in the world and is benchmarked for 16 times. Reynolds research on assessing the productivity of the UK retail sector gave the result that the Next is the No.1 in the space and employment efficiency measurement, and is No.2 in the capital and financial efficiency measurement. ${ }^{13}$

The following benchmarking company is the Truworths International Ltd., which is benchmarked for 15 times. The Truworths International Ltd. is the largest listed clothing and related merchandise retailer in South Africa, possess 600 outlets across South Africa. Adastria Holdings Co,. Ltd. and United Arrows Ltd. are benchmarked 10 and 9 times separately. They are mainly engaged in the apparel and miscellaneous goods retail business in Japan. GuruFocus Profitability Rank of Aug. 2014 referred that, Adastria Holdings Co., Ltd. has the Profitability Rank of 7 in the world, and it has a higher profitability and may stay that way in the next few years. H\&M is benchmarked for 7 times, Inditex and Fast Retailing Co. Ltd. are both benchmarked 5 times.

We are supprising at the TJX Companies, which ranked No.1 in the total revenue, but it is only benchmarked once, by the Gap. After analysing its input and output variables, we may deduct that the reason is that it has a too large scale to be benchmarked by other small size companies.

\section{Noe-efficient companies and degree of inefficiency}

Table 3 lists the results of input and output slacks. The 23 inefficient companies can improve their efficiency according to the input/output slack listed below. As we use the input-orientated DEA methodology, it is identified from the result that the inefficient companies can achieve efficiency frontier if the input values are reduced accordingly.

In this research, the reason of the 23 inefficient companies is from the 6 input aspects. For example, the Gap possesses too many stores and employees, if it reduces its number of employees and stores at
35757 and 568 respectively, it can get the economies of scale. L Brands, Inc. is too rich in total intangibles and stores, most of them are useless for the improving of output. Pou Sheng International (Holdings) Ltd has the biggest problem; we can see from the Table 3 that 5 out of 6 inputs should be deducted. Especially, its employees and stores should be reduced dramatically in $30 \%$ and $64 \%$ from the present level. Etam Development SA is another problem company, its employees and stores slacks are at 11663 and 2246, meantime, it should reduce its operating expenses and intangibles at USD24 million and USD109 million.

\section{Sensitivity test}

The main characteristic of DEA is its sensitive to variable selection and the chosen of DMUs. As the number of variables increases, the discrimination between the DMUs will decrease. Also more variables will increase the chance that some inefficient unit becomes efficient ones. ${ }^{30}$ Thus, the number of inputs and outputs should be kept at a reasonable level. Raab and Lichty suggested that the minimum number of DMUs should be greater than three times the number of inputs plus outputs. ${ }^{31}$ In this research, we use six inputs and two outputs, so minimum set should be 24 DMUs, here we employed 42 DMUs, and so the result of this research should be valid theoretically.

To test whether there were extreme outliers, we use the Jackknifing analysis, which can be used to test the robustness of the DEA results in regard to outliers. Bonesronning and Rattso used Jackknifing in their analysis, they ran DEA 34 times and dropped off one DMU every time. ${ }^{32}$ Mostafa used Jackknifing to test the stability of its study on the US specialty retailers and food consumer stores, but it's quite different from the research of Bonesronning and Rattso for he only dropped the efficient units that construct the frontier. In our research, we adopt the method of Mostafa. As there are 19 efficient companies in this research, we ran DEA 19 times and dropped out each efficient company one at a time. For the VRS, we ran 15 additional DEA analyses. The result showed that the correlations coefficients were all positive and significant, that is to say, the rankings of this study are stable in regard to determining the efficiency frontier.

Also, we test the stability by calculating the ratio of output/input values in efficient and inefficient companies see Table 4, it pointed out that the ratio of revenue to inputs in efficient companies exceeded those of inefficient companies greatly.

\section{Managerial implication}

Among the 42 apparel retail companies, 19 companies were showed performing well than the other 23. The slacks of these inputs variables in Table 3 can be used to help managers of the apparel firms to understand their weaknesses and give them suggestion of improving their efficiency and performance. For example, The Gap Inc., American Eagle Outfitters Inc. and Etam Developpement SA hired too many employees and operated excessive stores. They can deduct their employees and stores to increase their efficiency. But for the L. Brands, Inc., Esprit Holdings Ltd. and J. Crew Group, the main problem is their redundant intangibles. So the managers can adopt different strategies accordingly. 
Table 3 Input and output slacks

\begin{tabular}{|c|c|c|c|c|c|c|c|c|}
\hline Company & $\mathbf{X I}$ & $\mathbf{X} 2$ & $\mathbf{x} 3$ & $\mathbf{X 4}$ & $\times 5$ & $\times 6$ & YI & $\mathbf{Y 2}$ \\
\hline The TJX Companies, Inc. & 0 & 0 & 0 & 0 & 0 & 0 & 0 & 0 \\
\hline Industria de Diseno Textil SA & 0 & 0 & 0 & 0 & 0 & 0 & 0 & 0 \\
\hline$H$ \& M Hennes \& Mauritz AB & 0 & 0 & 0 & 0 & 0 & 0 & 0 & 0 \\
\hline The Gap, Inc. & 0 & 0 & 0 & 35757.33 & 567.522 & 0 & 0 & 3.258 \\
\hline Fast Retailing Co. Ltd. & 0 & 0 & 0 & 0 & 0 & 0 & 0 & 0 \\
\hline Nordstrom Inc. & 0 & 0 & 0 & 0 & 0 & 0 & 0 & 0 \\
\hline Ross Stores Inc. & 0 & 0 & 0 & 0 & 0 & 0 & 0 & 0 \\
\hline Foot Locker, Inc. & 0 & 0 & 0 & 0 & 2054.913 & 309.398 & 0 & 4.762 \\
\hline Next Plc & 0 & 0 & 0 & 0 & 0 & 0 & 0 & 0 \\
\hline Shimamura Co. Ltd. & 0 & 0 & 0 & 0 & 0 & 0 & 0 & 0 \\
\hline Ascena Retail Group Inc. & 0 & I I 2.004 & 556.393 & 4176.176 & $|372.20|$ & 0 & 0 & 1.716 \\
\hline Abercrombie \& Fitch Co. & 0 & 0 & 0 & 0 & 0 & 0 & 0 & 0 \\
\hline American Eagle Outfitters, Inc. & 0 & 122.885 & 25.069 & 10684.58 & 0 & 0 & 0 & 6.582 \\
\hline Esprit Holdings Ltd. & 0 & 542.433 & 546.417 & 0 & 0 & 0 & 0 & 0 \\
\hline Genesco Inc. & 0 & 0 & $|4| .276$ & 3274.572 & 828.789 & 191.11 & 0 & 0.423 \\
\hline The Men's Wearhouse, Inc. & 0 & 0 & 72.416 & 1043.365 & 0 & 255.736 & 0 & 6.44 \\
\hline Chico's FAS Inc. & 0 & 233.82 & 194.898 & 407.592 & 366.105 & 0 & 0 & 6.209 \\
\hline Edcon Holdings Limited & 0 & 0 & 1153.713 & 5027.08 & 81.409 & 87.291 & 0 & 9.728 \\
\hline Brown Shoe Co. Inc. & 0 & 0 & 0 & 0 & 214.404 & 151.319 & 0 & 7.79 \\
\hline J. Crew Group, Inc. & 0 & 55.845 & 2482.888 & 0 & 0 & 0 & 0 & 9.889 \\
\hline DSW Inc. & 77.057 & 0 & 0 & $|57| .095$ & 0 & 30.443 & 0 & 0.896 \\
\hline Aoyama Trading Company, Ltd. & 0 & 0 & 0 & 0 & 0 & 0 & 0 & 0 \\
\hline Pou Sheng International (Holdings) Ltd. & 12.09 & 0 & 133.576 & 6501.516 & 2869.226 & 337.81 & 0 & 16.181 \\
\hline AOKI Holdings Inc. & 0 & 0 & 0 & 0 & 0 & 0 & 0 & 0 \\
\hline Finish Line Inc. & 21.004 & 0 & 0 & 0 & 327.918 & || $4.63 \mid$ & 0 & 4.802 \\
\hline Etam Developpement SA & 0 & 24.257 & 108.724 & 11662.91 & 2246.232 & 83.895 & 0 & 2.52 \\
\hline Adastria Holdings Co., Ltd. & 0 & 0 & 0 & 0 & 0 & 0 & 0 & 0 \\
\hline Stage Stores Inc. & 159.122 & 0 & 0 & 5486.454 & 0 & 128.259 & 0 & 5.207 \\
\hline Claire's Stores Inc. & 0 & 0 & $|73| .727$ & 4064.535 & 2153.576 & $|7.94|$ & 0 & 8.171 \\
\hline Mr Price Group Limited & 0 & 0 & 0 & 0 & 0 & 0 & 0 & 0 \\
\hline The Foschini Group Limited & 0 & 0 & 0 & 0 & 0 & 0 & 0 & 0 \\
\hline United Arrows Ltd. & 0 & 0 & 0 & 0 & 0 & 0 & 0 & 0 \\
\hline Mothercare plc & 347.257 & 0 & 0 & 0 & 485.39 & 0 & 0 & 6.915 \\
\hline Maclntosh Retail Group NV & 0 & 0 & 106.33 & 3140.455 & 0 & $|29.88|$ & 0 & 0 \\
\hline Charles Voegele Holding AG & 0 & 0 & 0 & 0 & 0 & 0 & 0 & 0 \\
\hline Truworths International Ltd. & 0 & 0 & 0 & 0 & 0 & 0 & 0 & 0 \\
\hline New York \& Company Inc. & 0 & 0 & 0 & 0 & 0 & 0 & 0 & 0 \\
\hline Reitmans Canada Ltd. & 0 & 0 & 0 & 0 & 0 & 0 & 0 & 0 \\
\hline
\end{tabular}


Table 4 Comparison of efficient companies and inefficient companies

\begin{tabular}{llll}
\hline Ratio & Efficient(N= 19) & Inefficient(N=23) & Average \\
\hline Total revenue/cost of goods & 2.135387648 & 1.792211368 & 1.9638 \\
Total revenue/total operating expenses & 1.180438855 & 1.083326969 & 1.131883 \\
Total revenue/total intangibles & 279.0513885 & 26.26143413 & 152.6564 \\
Total revenue/number of employees & 0.340001654 & 0.165613977 & 0.252808 \\
Total revenue/number of stores & 6.065012872 & 2.556247545 & 4.31063 \\
Total revenue/inventory & 8.86917349 & 6.963493704 & 7.916334 \\
\hline
\end{tabular}

\section{Conclusion}

From the above study, it was concluded that in the top apparel retail market, 19 out of 42 companies are efficient. For the inefficient retailers, in order to be efficient, they need to adopt the strategies used by the efficient retailers. ${ }^{21}$ Here we discuss the operating patterns in the aspect of 6 inputs variables.

Cost of goods sold: As apparel retail is related to the sale directly, the more cost of goods sold, the more revenue can a company earn, so most of the companies don't have slacks in this input, only 6 of 23 inefficient companies need to improve their efficient in this input.

Total Operating Expenses: If a company's operating expense is more than the efficient level, which means wasting phenomenon is exist in this company. There are 8 companies need to reduce their expenditure of operating, the most wasteful company is Esprit Holdings Ltd., which should improve its efficiency by reducing $16 \%$ of its total operating expenditure.

Total intangibles: Total intangibles contain all kinds of intellectual properties; it represents the innovation capability of a company. But if a company possesses too much intangible than it can control, this kind of innovation may be useless and wasteful. L Brands, Inc. possesses USD1729 totally, ranked the second in the 42 companies, but $76 \%$ of the intangibles are unnecessary.

Number of employees: Apparel industry is a labour-intensive industry, and so are the retail stores. Managers are interested in recruiting a lot of employees to improve their revenue and result in an over-staffing for many companies. Table 3 shows that 16 companies, out of 23 companies are over-staffing, such as the Gap Inc., American eagle Outfitters Inc. etc.

Number of stores: This input has the same function as the number of employees. 14 companies should reduce their stores to increase their efficiency.

Inventory: Inventory represents the flow of the apparel retailers, it should be controlled at an appropriate level to ensure the company's fashionable. The higher inventory means the more unsaleable merchandise.

Actually, it may not always be possible for a company to become efficient by reducing the inputs because not all of the inputs are under the full control of local management. Different company has different mission and situation, the choice of cutting off the inputs is particular management perspective, so it is not recommended for the inefficient company to reduce their inputs according to the above result. The management strategy should be done by consulting with the companies under study so as to make the research more fruitful and useful for the study companies. ${ }^{21}$

\section{Research limitation and future research directions}

There are some limitations in this research. Firstly, this research only utilized the secondary data; it can't be able to capture executive opinions in the actual management. Secondly, the data were collected by the criteria of 2015 financial year, but different company has the different span of the financial year, so they are not representing the same period.

As this research does not distinguish the revenue generated from brick-and-mortar stores, online or mobile devices. It would be useful to consider the differences of retail channels in the future research. According to Barney Jopson and Stephen Foley in New York, the increase of apparel sales online has increased $10 \%$ approximately in the last five years. There are also pure-play retailers, e.g. Asos, Neta-Porter, that have become of substantial importance in the apparel retailing. It would be of great managerial significance to make this distinction and further scrutinise its efficiency of brick-and-mortar and online productivity.

\section{Acknowledgements}

None.

\section{Conflict of interest}

Authors declare there is no conflict of interest in publishing the article.

\section{References}

1. Jones R. The Apparel industry. Wiley-Blackwell; 2006. 328 p.

2. Barros CP, Alves C. An empirical analysis of productivity growth in a Portuguese retail chain using Malmquist productivity index. $J$ Retailing \& Consumer Services. 2004;11(5):269-278.

3. Taplin IM, Winterton J, Winterton R. Understanding Labour Turnover in a Labour Intensive Industry: Evidence from the British Clothing Industry. J Management Studies. 2003;40(4):1021-1046.

4. Doyle P. Marketing in the new millennium. European $J$ Marketing. 1995;29(13):23-41.

5. Richardson J. Vertical integration and rapid response in fashion apparel. Organization Science. 1996;7(4):400-412. 
6. Scott AJ. The changing global geography of low-technology, laborintensive industry: clothing, footwear, and furniture. World Development. 2006;34(9):1517-1536.

7. Tokatli N. Global sourcing: insights from the global clothing industrythe case of Zara, a fast fashion retailer. J Economic Geography. 2007;8(1):21-38.

8. Dickerson KG. Textiles and apparel in the global economy. 3rd ed. Merrill Upper Saddle River, NJ: Merrill; 1999. 606 p.

9. MarketLine. Global Apparel Retail. London: Progressive Digital Media Ltd; 2014. 34 p.

10. Gereffi G. International trade and industrial upgrading in the appare commodity chain. J international economics. 1999;48(1):37-70.

11. Lin SH, Kincade DH, Warfield C. Productivity and production in the apparel industry. International J Clothing Science \& Technology. 1994;6(1):20-27.

12. Uyar A, Bayyurt N, Dilber M, et al. Evaluating operational efficiency of a bookshop chain in Turkey and identifying efficiency drivers. International J Retail \& Distribution Management. 2013;41(5):331-347.

13. Reynolds J, Howard E, Dragun D, et al. Assessing the productivity of the UK retail sector. International Review of Retail, Distribution and Consumer Research. 2005;15(3):237-280.

14. Sellers-Rubio R, Mas-Ruiz F. An empirical analysis of productivity growth in retail services: evidence from Spain. International J Service Industry Management. 2007;18(1):52-69.

15. BIM. What is Productivity? England: Huddersfield.1976.

16. Donthu N, Yoo B. Retail productivity assessment using data envelopment analysis. J retailing. 1998;74(1):89-105.

17. Mostafa MM. Benchmarking the US specialty retailers and food consumer stores using data envelopment analysis. International J Retail \& Distribution Management. 2009;37(8):661-679.

18. Dubelaar C, Bhargava M, Ferrarin D. Measuring retail productivity: what really matters? J Business Research. 2002;55(5):417-426.

19. Bucklin LP. Productivity in marketing. Decatur: Marketing Classics Press; 2011. 117 p.
20. Barros CP. Efficiency measurement among hypermarkets and supermarkets and the identification of the efficiency drivers: a case study. International J Retail \& Distribution Management. 2006;34(2):135-154.

21. Gupta A, Mittal S. Measuring retail productivity of food \& grocery retail outlets using the DEA technique. J Strategic Marketing. 2010;18(4):277-289.

22. Keh HT, Chu S. Retail productivity and scale economies at the firm level: a DEA approach. Omega. 2003;31(2):75-82.

23. Barros CP, Alves CA. Hypermarket retail store efficiency in Portugal. International JRetail \& Distribution Management. 2003;31(11):549-560.

24. Bruce M, Daly L, Towers N. Lean or agile: a solution for supply chain management in the textiles and clothing industry? International $J$ operations \& production management. 2004;24(2):151-170.

25. Mittal V, Anderson EW, Sayrak A, et al. Dual emphasis and the longterm financial impact of customer satisfaction. Marketing Science. 2005;24(4):544-555.

26. Perrigot R, Barros CP. Technical efficiency of French retailers. J Retailing \& Consumer Services. 2008;15(4):296-305.

27. Young E, Wiecek IM. IFRS Primer International GAAP Basics. London: John Wiley; 2009. 384 p.

28. Mishra A, Ansari J. A conceptual model for retail productivity. International J Retail \& Distribution Management. 2013;41(5):348-379.

29. Charnes A, Cooper WW, Rhodes E. Measuring the efficiency of decision making units. European J Operational Research. 1978;2(6):429-444.

30. Yu W, Ramanathan R. An assessment of operational efficiencies in the UK retail sector. International $J$ Retail \& Distribution Management. 2008;36(11):861-882.

31. De Jorge Moreno J. Efficiency and regulation in Spanish hypermarket retail trade: A cross-section approach. International $J$ Retail \& Distribution Management. 2008;36(1):71-88.

32. Gandhi AV, Shankar R. Efficiency measurement of Indian retailers using Data Envelopment Analysis. International J Retail \& Distribution Management. 2014;42(6):500-520. 